Cristiano Fragassa
Assistant Professor
University of Bologna
$\begin{array}{r}\text { Bologna, } \\ \text { Italy }\end{array}$
Department of Industrial Engineering
Giuseppe Lucisano
Senior Researcher
Scm Group Spa
Consorzio Studi e Ricerche
Rimini,
Italy
Dragan Marinkovic
Research Assistant \& Lecturer
Technische Universität Berlin
Germany
Giampaolo Campana
Assistant Professor
University of Bologna
Bologna,
Italy

Cristiano Fragassa

Assistant Professo gineering

Italy

\section{A Practical Guideline in the Design and use of Woodworking Tools}

Circular saw blades, either with carbide or diamond inserts, are customarily embedded in wood working machines once they permit a precise and efficient manufacturing of wooden products starting from rawshaped solid wood chunks or laminate panels, allowing efficient processes and improving the overall industrial quality and competiveness of the final product. However, the parameters associated with blade design must be defined with caution, aiming to avoid undesirable cutting performance and consequent relevant detrimental impacts on both processes and equipment. Thus, based on the literature, the present investigation intends to collect and gather a consistent information set regarding the effect of changes in tool design parameters on manufacturing, particularly in the case of wood machining by circular saw blades with reinforced tips. The general outlook provided aims at pointing out essential frameworks and practical guidelines for a better comprehension of the most adequate criteria to be used in the design and choice of tools for each specific manufacturing condition.

Keywords: process quality, manufacturing, saw blades, tool design, wood machining.

\section{INTRODUCTION}

A circular saw is basically a power-saw that adopts an abrasive disc with teeth and blades properly designed to cut materials through a rotational motion around an arbour. This simple, but efficient tool is able to process different materials such as metal, plastic and wood. In addition, it may be easily hand-held or installed on a machine tool.

Circular saws were born at the end of the 18th century and spread in sawmills quickly enough, confirming the advantage offered by their utilisation [1].

Normally, the material part to be worked is fixed in a vise while the saw is slowly moved across it, but other solutions use a fixed saw with materials slowly advanced toward the saw blade. The teeth shape is especially designed for when a tooth strikes the material, the chips formed are driven out of the working area, preventing it from hindering the blade.
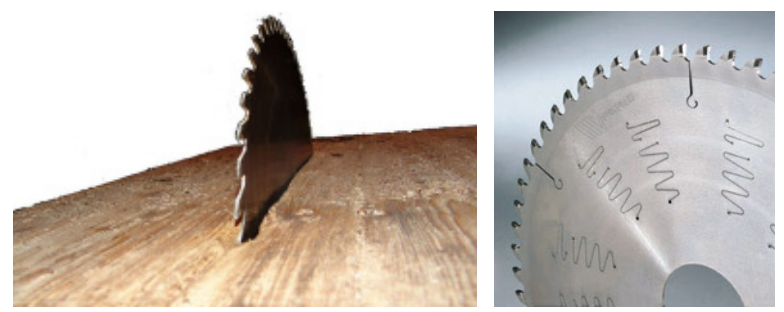

Figure 1. Using a circular saw in wood (left) processing and its details (right).

The large variety of machines suitable for cutting by

Received: January 2019, Accepted: March 2019

Correspondence to: Dr Cristiano Fragassa

Dept. Industrial Engineering, University of Bologna

Viale Risorgimento 2, 40136 Bologna, Italy

E-mail: cristiano.fragassa@unibo.it

doi: $10.5937 /$ fmet1903487F

(C) Faculty of Mechanical Engineering, Belgrade. All rights reserved circular saw blades includes: universal circular saws; circular saws for longitudinal cutting (ripping); circular saws for transversal cutting (crosscutting); squaring with engravers; cutting with engravers; and portable circular saw blades (Figure 1).

Circular saw manufacturing processes are mainly characterized by:

- $\quad$ cutting by teeth on the edge of a metal blade;

- the cut has narrow kerf and relatively smooth surface finish;

- $\quad$ cuts are straight and relatively accurate;

- the saw usually leaves burrs on the cut edge;

Aiming at optimizing the process and its quality, circular saws are specifically designed taking into consideration the particular material they are destined to work. In wood manufacturing, for instance, tools are specifically optimized for providing cross-cuts, rip-cuts or a combination of both.

Furthermore, as a result of the constant demand for productivity increase (e.g. by improving cutting speed and lifetime) [2], circular saw blades have been effected by never-ending changes in design. Currently, the latest technology for circular saw blades in heavy woodworking is represented by a hard metal core with polycrystalline diamond inserts that support the action of blades (Figure 2).

These tools allow a precise and efficient manufacturing of wooden products, both in the case of solid wood or laminate panels.

Even if focusing on the apparent simplicity of circular saw blades, it is also crucial to define all their design parameters with an extreme care. It is basically demonstrated, in fact, that slight modifications in these parameters could impact on relevant aspects of wood manufacturing such as process efficiency, surface finishing, tool durability, energy consumption, level of noise 
and many others. Even often unattended aspects like personal safety (e.g. high-speed projection of broken part of tools $[3,4]$ ) and environmental awareness (e.g. reducing wasted materials) could be also directly impaired in the case of inappropriate saw dimensioning. Not only limited to cutting tools, the risk could quickly fall back to the machine itself, given that an improper tool design provides unpredictable working conditions, especially related to temperatures, contact pressures, forces (intensity and direction) and vibrations. As consequence, producers oversize machine tools and users are asked to undersize their process parameters, where a significant efficiency improvement margin in the whole supply chain is merely disregarded due to poor design [5].

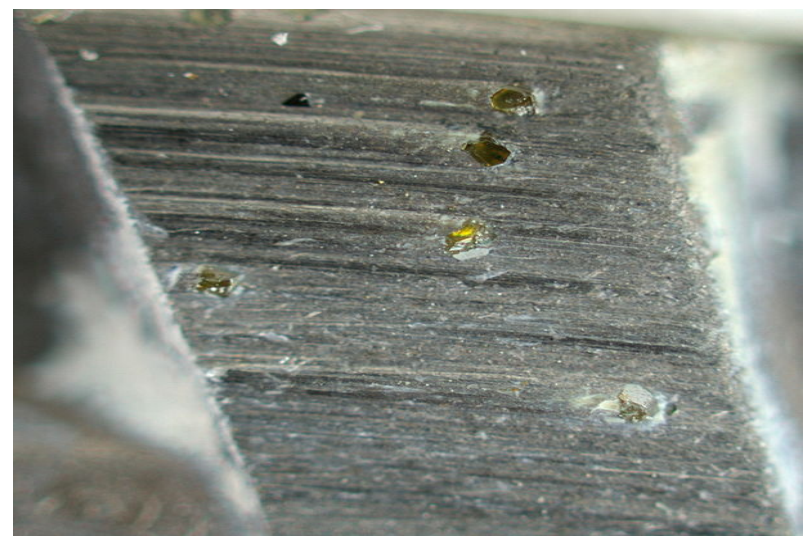

Figure 2. Synthetic diamond particles embedded on a metal blade.

This investigation intends to collect the most relevant information available on the effect of manufacturing design parameters (such as thinness and diameter for circular saw, number, dimension and shape for blades) and main process parameters (feed rate, rotational speed, etc.) in the case of wood machining using circular saw blades reinforced by diamond or tungsten carbide tips.

\section{LITERATURE OVERVIEW}

Since the scientific and technical literature regarding wood processing and manufacturing of wooden products is considerably wide, the definition of a limited list of references can be quite challenging. Although, acknowledged masterpieces in this sector can be surely considered [6-11]: all these books contribute to represent an introduction to wood engineering, starting from the essential principles of wood material science, passing by basic and advanced technologies and ending with a comparative discussion regarding the most relevant processes for wood-cutting.

Since these publications are several decades old, they can be conveniently used for a general overview about the argument and technology, while remarkable updates on the wood manufacturing processes is more recently proposed by [12] and [13].

Approaching the main topics of the present paper, several investigations regard the use of cutting tools in wood manufacturing. In particular, a preliminary analysis on cutting forces on equipment and tools during machining is proposed in [14] and in [15]. The discussion starts from the basic elements, but continues presenting the real situation in several applications from ordinary industrial processes. In $[16,17]$, the relation between strains and cutting force is investigated focused on a specific cutting processes and experiments. Beyond all the technical content expressed, it represents an example of the information available in similar papers, proposing specific analysis and potential solutions.

A different approach is [18] with the scope of merging information in practical models. In this case, a model able to envisage the cutting force during different phases of woodworking is described and represents a first step toward the development of a proper methodology for dimensioning tools and teeth in respect to the maximal stress they are subjected to.

Another aspect carefully investigated lately by researches is tool wear. A valid state of art regarding the overall phenomena of wear behaviour in tool during woodworking is represented by [16] while several analyses are focused on specific research topics, such as wear progression when polycrystalline diamond tools are used [19], and the effect of high-temperature on wearing in the case of tungsten carbide tools [20]. Wear is obstructed, by different expedients, as reported in [21], not only as a way to protect the cutting tool, extending its operational life and improving the general efficiency of the process, but also for a better quality of the final product.

When aiming for surface quality, it is usual to prioritize certain relevant parameters for selecting the most suitable cutting tool depending on the specific process applied. The correlation between the process parameters and their influence on the optimal cutting speed is an important aspect to provide efficient manufacturing [22]. Several studies investigate these aspects focusing on, for instance, the quality of the work piece surface when circular-saw blade presents irregular tooth pitch [23]. In this case, further researches permit the prediction of surface quality in machining only from the evaluation of tools and process parameters [24-25].

As depicted by [26], the knowledge on wood processing is far beyond that currently available for metals, where general correlations between process parameters are established with the aim at defining the most appropriate cutting speed. Specific procedures for the design optimisation of tools are already developed for metal cutting, using the Taguchi method, for instance [27]. Various fields of investigations are approached in works such as [28], where an active design is proposed for improving the precision of complex machine tools, or in [29], where the effect of several design parameters are experimentally evaluated for circular saw blades with self-clamped cutting inserts. This deep level of comprehension of cutting phenomena permits to implement intelligent controllers on cutting machines, able to self-reconfigure the process parameters toward its complete optimisation [30].

Regrettably, wood manufacturing is yet far away from that. It is evident that machining usually alters the shape, size and surface quality of wood, more than in the case of metals, for which several interesting studies are available, but the integration of this useful information in practical guidelines is missing.

In [31], for instance, an exhaustive description of the influence on the process of the specific materials under 
processing is proposed for the case of medium-density fibreboard (MDF).

There is also literature specifically focused on circular saws, main object of the current investigation. In [32], a stress/strain analysis of these tools is proposed with considerations based both on theoretical and experimental methods. Dynamic effects of circular saws are furthermore investigated in [33], where the variation of natural frequencies is analysed in respect to the tool geometry and process parameters, and in [34], where a nonlinear model representing the vibration of these thin tools is proposed.

In [35], the critical rotational speed is estimated presenting a simple method for its measure together with considerations on practical effects. Accordingly, in [36] a review on relevant developments regarding thin circular saws is proposed with the scope to assure a control of vibrations.

In [37], authors demonstrate a nonlinear vibration model of the woodworking band saw, and in [38, 39] the effect of the rotational speed on the natural frequencies of circular saw blades is analyzed proving the complex influence of slots on natural frequencies.

Table 1. List of design key parameters in tool definition.

\begin{tabular}{|c|c|c|c|}
\hline & Parameter & Unit & Range/Values \\
\hline \multirow{7}{*}{ 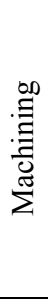 } & $\begin{array}{l}\text { Material being } \\
\text { machined }\end{array}$ & - & Various \\
\hline & Cutting Thickness & $\mathrm{mm}$ & $16-54$ \\
\hline & Cutting Speed & $\mathrm{m} / \mathrm{sec}$ & $10-80$ \\
\hline & Spindle Speed & $\mathrm{rpm}$ & $3.000-15.000$ \\
\hline & Feed Rate & $\mathrm{m} / \mathrm{sec}$ & $10-120$ \\
\hline & Noise Level & $\mathrm{dB}$ & $<101$ \\
\hline & Quality Surface & $\mathrm{Ra}$ & $0.2-10$ \\
\hline \multirow{8}{*}{$\begin{array}{l}\frac{n}{0} \\
0 \\
\bullet\end{array}$} & Core Material & - & Steel \\
\hline & Diameter & $\mathrm{mm}$ & $100-550$ \\
\hline & Core Thickness & $\mathrm{mm}$ & 3.5 \\
\hline & Teeth Thickness & $\mathrm{mm}$ & $4.4 / 4.6 / 4.8$ \\
\hline & Teeth & nr. & $48-72$ \\
\hline & Tip Thickness & $\mathrm{mm}$ & $1.6 / 2.0 / 3.2$ \\
\hline & Tip Granulometry & micron & $0.02-0.25$ \\
\hline & Lifetime & meter & $>1.000 .000$ \\
\hline
\end{tabular}

\section{USING A CIRCULAR SAW}

\subsection{Parameters List Definition}

Limiting the investigation to the case of circular saw blades, as first step, a preliminary list of the key parameters used in the definition of tools characteristics has been realized along with their range of variation or typical values (Table 1).

These parameters have been distinguished considering if referred to machining or tools.

\subsection{Spindle speed}

The spindle speed represents the frequency of the rotational movement of the spindle and it is measured in rounds per minute (RPM). Its range depends on the characteristics of the machine tool and its operational value is scarcely modulated during the manufacturing phases. Often, the machine tool is set at the highest spindle speed in respect to its design requirements for maximizing the productivity. At the same time, it is evident that the use of an appropriate spindle speed, different for each specific combination of material and tool, could significantly increase the tool life and improve the quality of the surface finish. Several investigations demonstrated that excessive spindle speeds may cause premature tool wear, breakages and tool chatter, all undesired phenomena which can lead to potentially dangerous conditions both for process and operators. As a consequence, the correct choice of the machine tool, with its related (and practically fixed) maximal spindle speed, represents an important technical factor to be properly considered.

The maximum spindle speed varies according to tool diameter with the intent of keeping the centrifugal forces under acceptable limits, given that as the rotational speed improves, the centrifugal force progressively increases. This relation can be extended to the tool diameter, once it is also directly proportional to the centrifugal force. In addition to the mechanical stresses, the centrifugal forces create undesired phenomena of instability and vibrations. As a consequence, beyond a critical threshold, the blade loses large part of its stiffness reducing the quality of cut and the life of the tool. Furthermore, a fast rotating blade can represent a dangerous situation for the operator, exposed to ejections of broken part of tools (e.g. tips) that emerge from the machine tool as high-speed projectiles.

The maximal spindle speed is suggested in Table 2, evaluated in consideration of tool resistance to mechanical stresses and instability.

Table 2. Maximal rotational speed vs. tool diameter.

\begin{tabular}{|c|c|c|c|c|}
\hline Diameter & Speed & & Diameter & Speed \\
\cline { 1 - 1 } \cline { 4 - 4 } $\mathrm{mm}$ & $\begin{array}{c}\mathrm{rpm} \\
\left(\mathrm{x} 10^{3}\right)\end{array}$ & & $\mathrm{mm}$ & $\begin{array}{c}\mathrm{rpm} \\
\left(\mathrm{x} 10^{3}\right)\end{array}$ \\
\hline 100 & 15 & & 200 & 9.0 \\
\hline 125 & 12 & 225 & 8.5 \\
\hline 150 & 12 & 250 & 8.0 \\
\hline 180 & 10 & & 280 & 6.5 \\
\hline 300 & 6.0 & 400 & 4.5 \\
\hline 320 & 5.5 & 450 & 4.0 \\
\hline 350 & 5.0 & 500 & 3.5 \\
\hline 380 & 4.5 & 550 & 3.0 \\
\hline$n n n$ & & &
\end{tabular}

\subsection{Cutting speed}

The cutting speed is the difference between the speeds of tool and the material, and can be considered the "most relevant single parameter" in the design of a tool or in its choose as suitable solution for a specific process. It has to be chosen considering the material from which the tool is realized, the inserts that constitute the cutting edges, the hardness of the material to be worked and the required level of finishing of the surface. In fact, the cutting speed is the main parameter that affects the working temperature and, therefore, the wear of the tool. To avoid heavy wear, hard materials are generally cut with low speeds reducing the stress between tools and surfaces. On the other hand, soft materials are typically worked with high speeds. During cutting, soft materials tend to demonstrate a kneading phenomenon, causing the removal of adhesion with the material and a strong loss of cutting effectiveness. 
This phenomenon can be reduced, up to its elimination, increasing the cutting speed. The cutting speed, that in the case of circular blades coincides with the peripheral speed, can be calculated by geometric considerations according to the following expression:

$$
V_{c}=\frac{\pi \times D \times R P M}{1000 \times 60}[\mathrm{~m} / \mathrm{s}]
$$

where $D$ is the diameter of the blade in $m m$ and $R P M$ represents the number of rounds per minute that define the speed of rotation of the tool. The chart below shows the trend of cutting speed in relation to the speed and the tool diameter (Figure 3).

By this analytical confrontation, having at disposal the diameter and the recommended cutting speed, it is possible to determine the optimal number of rounds per minute (spindle speed). Similarly, it is possible to derive the diameter or the cutting speed by placing the other two parameters.

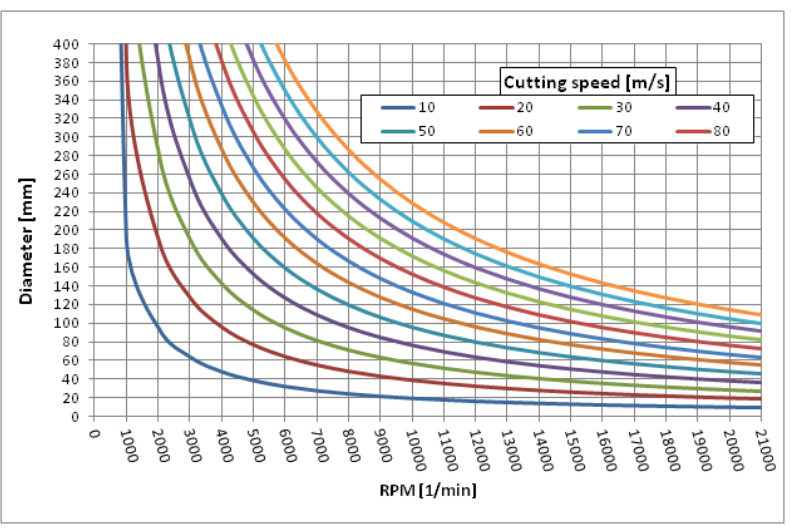

Figure 3. Cutting speed as function of diameter of tool and speed of rotation.

Generally, appropriate values for cutting speeds are proposed in combination with the specific material under manufacturing, where burns and rough cuts might be experienced in the case of inappropriate cutting speeds and long-term usage. These values are recommended by the tool manufacturer and tabulated in the tool catalogues according to the hardness of the material. Table 3 lists some recommended values for cutting speeds as a function of the worked materials.

Starting from the materials to be machined (a choice made according to products' needs) and after defined a specific tool diameter (according to the available machine tool), the spindle speed should be chosen so that the corresponding cutting speed is within the limits given in the table. The same motivation could be used to recommend a rotation speed for a given diameter of the tool. In this case, starting from the desired material and spindle speed, it could be possible to determine the cutting speed achieved by the tool, where it is preferable to keep this value as constant as possible (same for the spindle speed). Since the optimization of the cutting mechanisms is a really tricky task, it seems more convenient to select a specific machine tool, fix both spindle and cutting speeds, and act guided by only the tools parameters. In other words, the optimization of the manufacturing process is mainly focused on the choice of the right parameters for tools for each given mac- hining operation. In practical terms, it means that a change in the cutting tools is a very recurrent operation in respect to the modulation of the working parameters in machines as a response to changes in production needs. At the same time, Figure 3 can be used to verify if proper machine working parameters have been chosen.

Table 3: Recommended cutting speed for various materials

\begin{tabular}{|l|c|c|}
\hline \multirow{2}{*}{ Materials } & \multicolumn{2}{|c|}{ Cutting Speed [m/s] } \\
\cline { 2 - 3 } & min & Max \\
\hline Softwood & 70 & 100 \\
\hline Hardwood & 70 & 90 \\
\hline MDF & 60 & 80 \\
\hline Plywood & 60 & 80 \\
\hline Hard Plywood & 60 & 80 \\
\hline Chipboard & 60 & 120 \\
\hline
\end{tabular}

\subsection{Feed rate}

The feed rate represents the speed at which the cutter is fed and advances against the material. It is expressed in units of distance per round and has a direct impact both on productivity and quality finishing. In general, the feed rate dependents on several aspects: type of tool; surface finish desired; power available at the spindle (to avoid stalling of workpiece or blades); stiffness of the structures and tooling setup (capability to tolerate vibration or chatter); strength of the workpiece (high feed rates will failure thin wall tubing); and peculiarities of the material under processing.

In particular, the geometry of the tool edges and the density of materials under processing represent a combination of factors to be considered since their influence on the ability of the blade to evacuate the chips from the cutting area. Chip flow strongly depends on material type and feed rate.

The density of chips and, as consequence, their transportability, depend on the material to be machined, in particular by the type of chip produced and by the possibility to evacuate them. The ideal chip shape is small and breaks free early, carrying heat away from the tool and work area.

In general terms, the surface quality depends on several cutting parameters used to carry out the machining, together with several geometrical characteristics for tools (mainly related to layout, shape and size of the peripheral cutting edges).

Referring to the first aspect, the tool rotation combined with the linear advancement creates a ripple on the surface, which results in a higher final surface roughness. The surface quality primarily depends on the distance, the depth and regularity of grooves, but also on the diameter of the cutting edges, the number of rounds and the feed rate. Improving the feed rate without an appropriate rearrangement of the other parameters, like in the case of a quick response to a temporary peak of productivity, will drastically reduce the quality of the surface.

In woodworking, the ideal feed rate represents a relevant parameter, impacting at the level of processes and competitiveness. Ideally, the process must be slow enough not to bog down the engines or to limit the 
surface finishing, yet fast enough to avoid burning the material. Thus, the feed rate also becomes an important parameter in the design of high quality tools, defined as:

$$
V_{f}=\frac{f_{z} \times R P M \times z}{1000}[\mathrm{~m} / \mathrm{min}]
$$

where $z$ is the number of teeth while $f_{z}$ represents the feed per tooth, defined by:

$$
f_{z}=\frac{V_{f}}{R P M \times z} \times 1000[\mathrm{~mm}]
$$

This advancement of the tooth, usually named as feed per tooth (or chip load since it represents the size of chip that each tooth of the cutter takes) must not exceed certain values which depend on the tool type and the type of material to be machined. Table 4 lists the recommended values of feed per tooth for some materials.

Table 4. Recommended feed per tooth for various materials [Leitz and Freud catalogues].

\begin{tabular}{|l|c|c|}
\hline \multirow{2}{*}{\multicolumn{1}{c|}{ Material }} & \multicolumn{2}{c|}{$\begin{array}{c}\text { Feed per tooth } \\
\text { [mm/tooth] }\end{array}$} \\
\cline { 2 - 3 } & Leitz & Freud \\
\hline Softwood (along natural grains) & $0.20-0.90$ & $0.20-0.30$ \\
\hline Softwood (transversally to grains) & $0.10-0.20$ & $0.10-0.20$ \\
\hline Hardwood & $0.05-0.15$ & $0.06-0.15$ \\
\hline Plywood & $0.10-0.25$ & $0.10-0.25$ \\
\hline Composites & $0.05-0.12$ & $0.05-0.05$ \\
\hline Veneered & $0.05-0.12$ & $0.05-0.05$ \\
\hline Chipboard & $0.05-0.10$ & $0.05-0.10$ \\
\hline Melamine Faced Chipboard & $0.02-0.05$ & $0.02-0.10$ \\
\hline Aluminum & $0.02-0.05$ & $0.02-0.05$ \\
\hline
\end{tabular}

\section{COUNTING ON TEETH}

\subsection{Teeth in simultaneous contact}

It is essential that the blades and, in particular the geometry of their teeth, are properly dimensioned compared to the size of the panel, especially in respect to its thickness. During conventional cuts, blades have to cross the panel throughout its thickness while the tooth is following a trajectory based on an arc of circle (Figure 4). The projection of the blade regarding the work piece must be, at least, equal to the height of the tooth of the blade itself. A change in the projection, up or down, may affect significantly the quality of the finish.

Another fundamental parameter for a correct cutting process is represented by the number of teeth in mesh (Zp) that are in simultaneous contact with the workpiece, representing the number of teeth able to cut the wood concurrently in the way to reduce the local stress in each area. It is common to have at least 3 or 4 teeth in mesh; with less than three teeth, the blade begins to vibrate, causing an uneven and poor-quality cutting. The correct value depends on several aspects, primarily on the hardness of the material under manufacturing. Improving the number of teeth (and tips) beyond a reasonable limit can burst the costs and complexity of cutting tools without any advantage for the process.

At the same time, it is important to highlight that the number of teeth is a relevant parameter acting on several aspects of the cutting process, not to be overlooked.
Once fixed the diameter (D) for the blade to maintain a good quality in the cut, it is necessary to decrease the number of teeth in accordance with an increase of the thickness (T) of the material. On the contrary, increasing the number of teeth would decrease the thickness of the work piece. This second rule arises from the need to evacuate the chips produced in machining: until the tooth is in mesh, the chip is seated in the recess formed in the blade at the base of the tooth. This condition determines the need to increase the space destined to housing temporary chip in the blade.

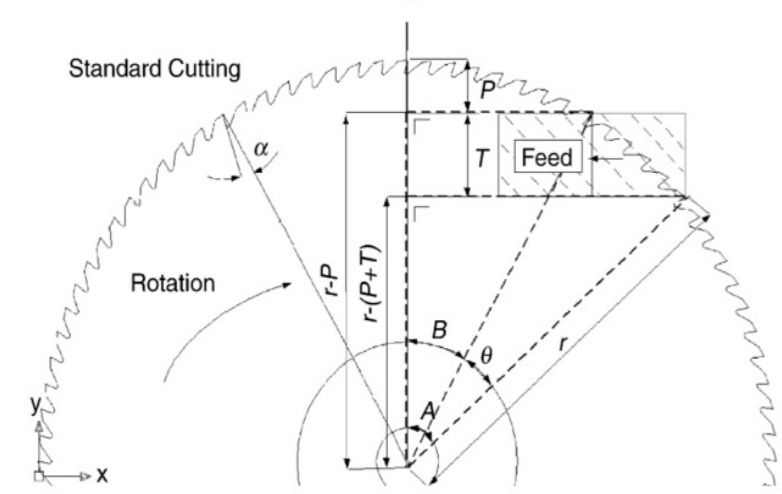

Figure 4. Geometrical configuration in the case of panel cutting by circular saw blades [Todd, 1994].

A practical way for tooth dimensioning passes by the estimation of the pitch (p) between the teeth, equal to the distance between the teeth along the circumference of the blade, as following:

$$
p=\sqrt{2} \times \frac{T}{z_{p}}
$$

Basically, it is necessary to multiply the thickness of the work piece to approximately 1.41 and divide by 3 , if it is believed that 3 teeth in mesh are appropriate for finishing, or by 4 , if it is preferable to have an additional tooth in contact.

Considering that, in general, the following relation is also valid:

$$
p=\pi \times \frac{D}{z}
$$

where $\mathrm{Z}$ is the total number of teeth in the blade, it is possible to obtain this value as:

$$
Z=\frac{\pi}{\sqrt{2}} \times \frac{D}{T / Z_{p}}=2.22 \times Z_{p} \times \frac{D}{T}
$$

considering the alternative case of $\mathrm{Zp}=3$ or 4 .

In practice, with the aim at obtaining a recommendation in the number of teeth for a circular saw blade, it is possible to multiply per 8 its diameter and divide per thickness of work piece. This result represents a valid suggestion for a standard cutting process with cuts made transversally to natural grains in the case of wood, chipboard, plywood and MDF.

This formula, leading to useful practical results as reported in Table 5, has to be adapted in all the other cases, such as cuts along natural grains, softer or harder materials and presence of protective surfaces. 
Table 5. Recommended minimal number of teeth for several combinations of tool diameter and work piece thickness in the condition of, respectively, 3 or 4 teeth in contact.

\begin{tabular}{|r|c|c|c|c|c|c|}
\hline Diameter & \multicolumn{7}{|c|}{ Thickness [mm] } \\
\cline { 2 - 7 }$[\mathbf{m m}]$ & $\mathbf{2 0}$ & $\mathbf{4 0}$ & $\mathbf{6 0}$ & $\mathbf{8 0}$ & $\mathbf{1 0 0}$ & $\mathbf{2 0 0}$ \\
\hline 100 & $33 / 44$ & $17 / 22$ & - & - & - & - \\
\hline 150 & $50 / 67$ & $25 / 33$ & - & - & - & - \\
\hline 200 & $67 / 89$ & $33 / 44$ & - & - & - & - \\
\hline 250 & $83 / 111$ & $42 / 56$ & $28 / 37$ & - & - & - \\
\hline 300 & - & $50 / 67$ & $33 / 44$ & $25 / 33$ & - & - \\
\hline 350 & - & $58 / 78$ & $39 / 52$ & $29 / 39$ & $23 / 31$ & - \\
\hline 400 & - & $67 / 89$ & $44 / 59$ & $33 / 44$ & $27 / 36$ & $13 / 18$ \\
\hline 450 & - & $75 / 100$ & $50 / 67$ & $37 / 50$ & $30 / 40$ & $15 / 20$ \\
\hline 500 & - & $83 / 111$ & $56 / 74$ & $42 / 56$ & $33 / 44$ & $17 / 22$ \\
\hline
\end{tabular}

\subsection{Effective length of cut}

The effective cutting length can be calculated using the geometrical features of the length of the linear cut, which is the path of the tooth during cutting through the panel being processed according to an arc of circumference pattern. The length of the path depends on the thickness and the geometry of the blade. This parameter can be useful to assess with great precision the actual duration of the sharpening of the cutting edges, taking into account the thickness of the material cut, while usually there is content to roughly estimate the length through sharpening the length of the linear cut. Several investigations propose a relationship between the linear length of cut and the effective length of cutting in reference to a single tooth of the tool, being possible to notice that teeth are very exploited when the feed per tooth is reduced.

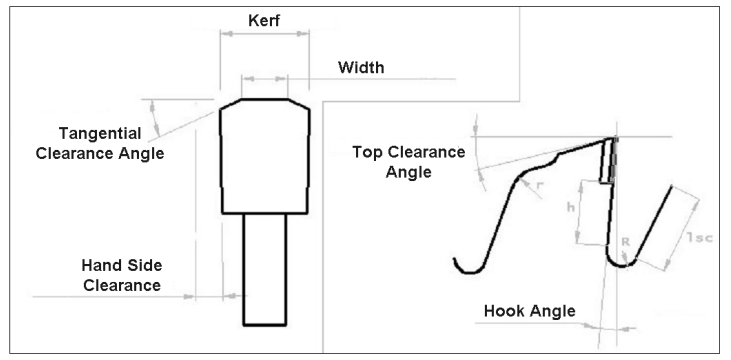

Figure 5: Main design parameters of a tooth

\section{DEFINING GEOMETRIES}

\subsection{Hook angle}

The optimal hook angle varies in accordance with the thickness of the workpiece: higher thicknesses infer higher angles for a proper cutting. It is worth to notice that positive hook angles (from $10^{\circ}$ to $20^{\circ}$ ) induce efficiency in fast cutting and easy feeding, especially in ripping applications. At the same time, close to zero or negative hook angles (e.g. $-2^{\circ}$ ) minimize climbing permitting a better control in cuts.

There is not a well-determined relation between these two parameters and dimensioning is only possible based on previous experience. Usually, the highest values for the work piece are around $100 \mathrm{~mm}$, equal to a stack of 5 panels with $20 \mathrm{~mm}$ each. For this thickness, a valid hook angle could be represented by $15^{\circ}$. Other common combinations of values for hook angle as a function of thickness are reported in the Table 6 .
Table 6: Hook angle in accordance with thickness of the workpiece.

\begin{tabular}{|c|c|}
\hline Thickness & Hook angle \\
\hline 20 & $6^{\circ}$ \\
\hline 40 & $8^{\circ}$ \\
\hline 60 & $10^{\circ}$ \\
\hline 80 & $12^{\circ}, 13^{\circ}$ \\
\hline 100 & $14^{\circ}, 15^{\circ}$ \\
\hline
\end{tabular}

The optimization of the hook angle is relevant for each particular material, since it can radically change the mechanics of cutting (Table 7). For instance, negative hook angle helps prevent the blade from being too aggressive and pushes the work piece down and toward the fences, yielding an appropriate solution for hard materials. On the contrary, for softer materials, high values of hook angle are advised to improve the machinability.

In practice, a hook angle between $15^{\circ}$ and $25^{\circ}$ is adequate for soft and hard woods, including exotic woods. The higher is the hardness of the processed material, the lower the angles should be. A value between $5^{\circ}$ and $15^{\circ}$ is suitable, for instance, for chipboard and other soft wood laminates such as MDF. Hook angles between $0^{\circ}$ and $5^{\circ}$ are more appropriate for plywood or veneered, and sometimes less than zero for melamine bi-faced chipboard.

Negative angle like $-10^{\circ}$ are also quite common for harder subjects such as aluminium or other non-ferrous materials, even if used in combination with wood.

Table 7: Hook angle in accordance with materials under processing.

\begin{tabular}{|l|c|}
\hline \multicolumn{1}{|c|}{ Material } & Hook Angle \\
\hline Softwood - Hardwood & $15^{\circ}-25^{\circ}$ \\
\hline Chipboard, MDF & $5^{\circ}-15^{\circ}$ \\
\hline Plywood, Veneered & $0^{\circ}-5^{\circ}$ \\
\hline Melamine Faced Chipboard & $-5^{\circ}-5^{\circ}$ \\
\hline Aluminum Composites & $-10^{\circ}-0^{\circ}$ \\
\hline
\end{tabular}

\subsection{Top Clearance Angle}

The top clearance angle (or relief angle) can increase or decrease in accordance with the hardness of the material being machined. In the case of more than one material under process, a proper combination of values associated with their hardness has to be taken into account. Higher the hardness is, lower the top clearance angle has to be. This value has also to be changed in consideration of the thickness: consequently, after the proposition of an appropriate according to experiences that regard the effect of hardness, this value should be slightly corrected (limiting this correction to few degrees) in consideration of the thickness of work piece. The angle has to be increased in the case of thicknesses higher than 80-100 mm and decreased if lower than 20-40 mm.

\subsection{Tangential Clearance Angle}

The tangential clearance angle also changes with the hardness of the machined material. Harder materials need higher angles with the aim at avoiding chips on surfaces. It varies from $25^{\circ}$ for relatively soft materials, up to $45^{\circ}$ for harder ones. 


\subsection{Radial Clearance Angle}

The radial clearance angle is also an associative parameter (not estimable by theory or simulations) in relation with the thickness of the work piece. It varies from $-1^{\circ}$ in the case of thicknesses around $20-40 \mathrm{~mm}$, down to $-2^{\circ}$ for $80-100 \mathrm{~mm}$.

\subsection{Tool Width}

The width of the saw blade body (also called as plate) varies according to the overall width of the tool.

Table 8. Tool widths in accordance with the tool diameters.

\begin{tabular}{|c|c|}
\hline Tool Diameter & Tool Width \\
\hline $100-199$ & 2.2 \\
\hline $200-349$ & 2.8 \\
\hline $350-449$ & 3.2 \\
\hline $450-599$ & 3.5 \\
\hline $600-750$ & 4.0 \\
\hline $100-199$ & 1.8 \\
\hline $200-349$ & 2.2 \\
\hline $350-449$ & 3.2 \\
\hline $450-599$ & 3.5 \\
\hline $600-750$ & 4.0 \\
\hline
\end{tabular}

The latter is determined by the specific manufacturing process and equipment used, whereas large plates assure tool stability and resistance. However, as previously detailed, the tool width is related with its diameter. It is not possible to define a strict connection between these parameters, but some values from experiences are proposed in Table 8.

\subsection{Land}

The land is generally around $45-60 \%$ of the overall tooth size, but it can vary depending on the hardness of the material, where higher sizes for land correspond to higher hardness. Also in this case, the proper values can only be defined by experiences.

\section{CONCLUSION}

A practical procedure for the design and use of circular saw blades in woodworking is hereby proposed.

Circular saw blades, with carbide or diamond inserts, can represent the optimal solution in wood manufacturing since these tools permit fast and efficient cuts improving the process competiveness along the productive chain.

At the same time, several design requirements have to be considered with attention to avoid unpredictable impacts on relevant aspects of processes and equipment. This investigation provides useful information on the effect on manufacturing of the tool design parameters and main process parameters in the case of wooden materials and circular saw blades with reinforced tips. Considering the factual inexplicability ruling some of the main parameters of tool design in respect to process effects, a simplified methodology was proposed.

Data retrieved from specific experiments and common best practices in wood processing were also considered. Results are in line with the several funda- mental rules used for tools design usually applied by tool manufacturers or vendors.

Providing a general overview of the subject, this research has the scope to define a framework of rules, formulae and practical prescriptions able to provide a better understanding regarding the criteria used in the selection of the proper tool for each specific manufacturing condition. The present work provides a clear definition of the most relevant design parameters in tools design and handling, together with a sort of ranking regarding their relative importance for the quality of the final product, including the proposition of a list of suggestions to be used in defining the correct spindle speed and cutting speed to ensure the stability of the circular blade. These considerations are related to the diameter of blade and to the specific material under processing. Adding, it is noteworthy that the spindle speed is mainly dependent on the specific tool machine and the cutting speed can be gathered from that.

On the contrary, if the machine is not already available in the factory, a relation can be used for dimensioning the equipment as a whole according to the production target.

As following step, a method able to estimate the proper feed rate is also proposed, considering its close relation with the machining speed and the number of teeth. The selection of an adequate value depends on a compromise between high speed in processing, excellent surface quality and ability of the blade to push away the chips from the working area. This evaluation passes by the concept of teeth in simultaneous contact with the aim at correctly distribute the cutting forces on an appropriate number of teeth, thus reducing risky stress concentrations on blades or machined materials. Also, the effective length of cut was presented as an interesting way to estimate the endurance of the cutting tools.

Finally, some general considerations are presented related to the specific shape of teeth such as hook angle, top clearance, overall dimensions and their impact on the final cut.

\section{ACKNOWLEDGMENT}

This investigation has been implemented as part of the industrial research and innovation activity performed inside the collaborative project 'Custom Cutting Tools', EUREKA's Eurostars Programme. Special thanks to Mauro Pasquini (Wirutex) for his support.

\section{REFERENCES}

[1] Goodman, W. L.: The history of woodworking tools. David Mc Kay Company, 1976.

[2] Lucisano, G., Stefanovic, M., and Fragassa, C.: Advanced Design Solutions for High-Precision Woodworking Machines, International Journal of Quality Research, Vol. 101, pp. 143-158, 2016.

[3] Pavlovic, A., and Fragassa, C.: Analysis of flexible barriers used as safety protection in woodworking, International Journal of Quality Research, Vol. 101, pp. 71-88, 2016.

[4] Pavlovic A, and Fragassa, C.: Numerical modelling the ballistic impacts on flexible curtains used as 
safety protection in woodworking, Proceedings of the Institution of Mechanical Engineers, Part C: Journal of Mechanical Engineering Science, Vol. 2311, pp. 44-58, 2017.

[5] Djapic, M., Lukic, L.J., Pavlovic, A: An approach to machine tools structure selection for wooden product machining based on evidence networks, FME Transactions, Vol. 44, No. 4, pp. 365-373, 2016.

[6] Kollmann, F.F.P., and Cote, W.A.: Principles of Wood Science and Technology: I Solid Wood. Springer-Verlag, 1968.

[7] McKenzie, W. M.: Fundamental analysis of the wood-cutting process, University of Michigan, 1961.

[8] Franz, N. C.: An analysis of the wood-cutting process. University of Michigan Press, Ann Arbor, US, 1966.

[9] Jawaid, M., Thariq, M. (Editors): Handbook Sustainable Composites for Aerospace Applications, Woodhead Publishing - Elsevier, Cambridge, 2018.

[10]Zweben C.H., Beaumont P.W.R. (Editors): Comprehensive Composite Materials II, 2nd Edition, Elsevier Ltd., Amsterdam, 2018.

[11] Beaumont P.W.R., Soutis C., Hodzic A. (Editors): Structural integrity and durability of advanced composites: Innovative modelling methods and intelligent design, Woodhead Publishing - Elsevier, Cambridge, 2015.

[12] Todd, R., Allen, D. K., Alting, L.: Manufacturing Processes Reference Guide. Industrial Press, 1994.

[13] Kalpakjian, S., and Schmid, S.R.: Manufacturing Processes for Engineering Materials, Prentice Hall Pearson Education, 2008.

[14] Marchal, R., Mothe, F., Denaud, L., Thibaut, B., and Bleron, L.: Cutting forces in wood machining Basics and applications in industrial processes. Wood machining - micromechanics and fracture, Holzforschung, Vol. 63, No. 2, pp. 157-167, 2008.

[15] Eyma, F., Méausoone, P.J., and Martin, P.: Strains and cutting forces involved in the solid wood rotating cutting process, Journal of materials processing technology, Vol. 148, No. 1, pp. 220225, 2004.

[16] Klamecki, B.E.: A review of wood cutting tool wear literature, Holz als Roh-und Werkstoff, Vol. 37, No. 7, pp. 265-276, 1979.

[17] Popovic, M., Tanovic, L., Ehmann, K.F: Cutting forces prediction: The experimental identification of orthogonal cutting coefficients, FME Transactions, Vol. 45, No. 4, pp. 459-467, 2017.

[18] Naylor, A., Hackney, P., Perera, N., and Clahr, E.: A predictive model for the cutting force in wood machining developed using mechanical properties, BioResources, Vol. 7, No. 3, pp. 2883-2894, 2012.

[19] Philbin, P., and Gordon S.: Characterisation of the wear behaviour of polycrystalline diamond PCD tools when machining wood-based composites, Journal of Materials Processing Technology, Vol. 162-163, pp. 665-672, 2005.
[20] Sheikh-Ahmad, J.Y., Bailey, J.A.: High-temperature wear of cemented tungsten carbide tools while machining particleboard and fibreboard, Wood Science Journal, Vol. 45, pp. 445-455, 1999.

[21] Labidia, C. et al.: Surface treatments of tools used in industrial wood machining, Surface and Coatings Technology, Vol. 200, pp. 118-122, 2005.

[22] Barcík, Š., et al.: The influence of cutting speed and feed speed on surface quality at plane milling of poplar wood, Wood research, Vol. 54, No. 2, pp. 109-115, 2009.

[23] Kopecky, Z., Rousek, M., Halaskova, L. et al.: Quality of the work piece surface at cutting by a circular-saw blade with the irregular tooth pitch, Annals of Warsaw: University of Life SciencesSGGW. Forestry and Wood Technology, Vol. 74, 2011.

[24] Tóth-Laufer, E., Horváth, R.: Fuzzy model based surface roughness prediction of fine turning, FME Transactions, Vol. 45, No. 1, pp. 181-188, 2017.

[25] Lu, C.: Study on prediction of surface quality in machining process, Journal of materials processing technology, Vol. 2051, No. 439-450, 2008.

[26] Astakhov, V.P., and Osman M.: Correlations amongst process parameters in metal cutting and their use for establishing the optimum cutting speed, Journal of materials processing technology, Vol. 62, No. 1, pp. 175-179, 1996.

[27] Yang, W.H., and Tarng, Y.S.: Design optimization of cutting parameters for turning operations based on the Taguchi method, Journal of Materials Processing Technology, Vol. 84, No. 122-129, 1998.

[28]Xu, X.W., and Newman, S.T.: Making CNC machine tools more open, interoperable and intelligent - $\mathrm{a}$ review of the technologies. Computers in Industry, Vol. 57, pp. 141-152, 2006.

[29] Chang, W.T., and Chen, L.C.: Design and experimental evaluation of a circular saw blade with self-clamped cutting inserts, Int J Adv Manuf Technol., Vol. 83, No 1-4, pp. 365-379, 2016.

[30] Xu, Y. et al.: Active precision design for complex machine tools: methodology and case study, Int $J$ Adv Manuf Technology, Vol. 80, pp. 581-590, 2015.

[31] Aguilera, A., Meausoone, P.J., and Martin, P.: Wood material influence in routing operations: the MDF case, European Journal of Wood and Wood Products, Vol. 58, No. 4, pp. 278-283, 2000.

[32] Szymani, R., Mote, C. D.: Theoretical and Experimental Analysis of Circular Saw Tensioning. Wood Science and Technology, Vol. 13, pp. 211-237, 1979.

[33] Andelic, N., Pavlovic, A., Braut, S.: Variation of Natural Frequencies by Circular Saw Blade Rotation, Tehnički vjesnik, Vol. 25, No. 1, pp. 10-17, 2018.

[34] Zigulic, R., Fragassa, C, Skoblar, A. Influence of the longitudinal displacement on nonlinear principal parametric resonance of the woodworking bandsaw, Tehnicki Vjesnik, Vol. 241, pp. 253-263, 2017. 
[35] Orlowski, K., Sandak J., Tanaka C.: The critical rotational speed of circular saw: simple measurement method and its practical implementations, Journal of Wood Science, Vol. 53, pp. 388-393, 2007.

[36] Mote, C. D., and Szymani, R.: A Review Report on Principal Developments in Thin Circular Saw Vibration and Control Research. Part I : Vibration of Circular Saws, Holzals Rob- und Werkstoff, Vol. 35, pp. 189-196, 1977.

[37] Kulig, T.: Band-Saw Blade Estimator, Proceedings 12th Winona Computer Science Undergraduate Research Seminar, 24 ${ }^{\text {th }}$ April 2012, Winona, US, pp. 8-12.

[38] Leitz Lexikon: General Catalogue 6th Edition, Leitz GmbH and Co, KG, Oberkochen, 2011.

[39] Fraud: General Products Catalogue. Fraud America Inc., 2011.

\section{ПРАКТИЧНА СМЕРНИЦА У ДИЗАЈНУ И} УПОТРЕБИ АЛАТА ЗА ОБРАДУ ДРВЕТА

\section{К. Фрагаса, Ђ. Лућисано, Д. Маринковић, Ђ. Кампана}

Листови кружне тестере, било са карбидним или дијамантским уметцима, уобичајено су уграђени у машине за обраду дрвета када је неопходна прецизна и ефикасна производња дрвених производа почевши од сирових комада масивног дрвета или ламинатних панела, омогућавајући ефикасне процесе и побољшавајући укупни индустријски квалитет и конкурентност финалног производа. Међутим, параметри повезани са дизајном сечива морају бити дефинисани са опрезом, са циљем да се избегну нежељене перформансе резања и значајни штетни утицаји на процесе и опрему. Према томе, на основу литературе, овим истраживањем се намерава прикупити значајан скуп информација о учинку промена параметара конструкције алата на производњу, посебно у случају обраде дрвета кружним тестерама са ојачаним врховима. Наведени општи изглед има за циљ да истакне суштинске оквире и практичне смернице за боље разумиевање најадекватнијих критеријума који се користе у дизајну и избору алата за свако специфично стање производње. 